\title{
Hazards and Improvement Measures of Microplastic Pollution : A Review
}

\author{
Quan Gan ${ }^{1, a, \dagger}$, Jinxiao Tian ${ }^{2, \mathrm{~b}, \dagger}$, Zhixin $\mathrm{Li}^{3, \mathrm{c}, \dagger}{ }^{\dagger}$, Shiyu Mi ${ }^{4, \mathrm{~d}, \dagger}$, Wenmin Wang ${ }^{5, *}$ \\ ${ }^{1}$ Reading Academy, Nanjing University of Information Science and Technology, Nanjing 210044, China. \\ ${ }^{2}$ College of Chemistry, Sichuan University, Chengdu 610041, China. \\ ${ }^{3}$ College of Natural Resources and Environment, South China Agricultural University, Guangzhou 510642, China. \\ ${ }^{4}$ School of Environment, Beijing Normal University, Beijing 100875, China. \\ ${ }^{5}$ Shenzhen International Graduate School, Tsinghua University, Shenzhen 518055, PR China. \\ †These authors contributed equally.
}

\begin{abstract}
Microplastics is one category of plastics with relatively small diameter and is considered as the common ingredient of waste accumulation zone in oceans. However, since countless plastic products are emitted into oceans annually as waste all around the world, pollution caused by them is severe and the resulting problems have attracted attention globally, while current policies and cooperation around the globe for tackling microplastics pollution still need to be improved. To deal with microplatics-related problems in the ocean, our review first discussed the toxicity of microplastics based on previous research related to marine microplastics, which was caused by the plastics themselves and their leaching substances with impacts on marine creatures and human body along the food chain. After summarizing some measures that have been already performed, we suggested that the authority should take more actions to mitigate those problems resulted from microplastics, pay more attention on researching, and encourage citizens to offer their proposals. By finally analyzing the advantages and disadvantages of different handling methods, as well as physical, chemical, and biological treatment technologies on oceanic microplastic issues, our work provided experience on disposing microplastics waste under various actual situations with an example for more holistic waste treatment.
\end{abstract}

\section{Introduction}

Plastics is one of the most commonly used materials in our daily life and its products have always been highly demanded around the globe. The Association of Plastics Manufacturers in Europe showed that 50.7 million tonnes of plastics were demanded in 2019 only for European countries[1]. And this considerable need came from its diversified utilizations, which was mostly for packaging and closely followed by construction industry [1]. In 2019, there was globally 370 million tonnes of plastic being produced [1]. The outbreak of COVID-19 in 2020 also boosted plastic production worldwide on personal protective equipment (PPE) since the effective protective equipment was mainly composed of plastics $[2,3]$. However, discarding plastics has been lasting for several decades and relatively poor management of plastic garbage has caused environmental problems. Most plastic products, such as polyethylene and polystyrene, could not be degraded in the environment, and thus might exist for several hundreds or thousands of years, amassing with time [4]. There were 4.8 to
12.7 million metric tons of plastics entering the global oceans in 2010 [5]. Since most plastic products are lighter than seawater, despite some might be shattered into powders, they return to lands or sink into deep oceans when emitted into oceans, while the remaining portion can float on the water surface and be transported by ocean currents and sea breeze, eventually moving into major circulation centers over the sea and forming plastic accumulation zones[6-10]. One representative example of this is between Hawaii and California called Great Pacific Garbage Patch (Fig. 1), of which microplastics composing 94 percent $[6,11,12]$.

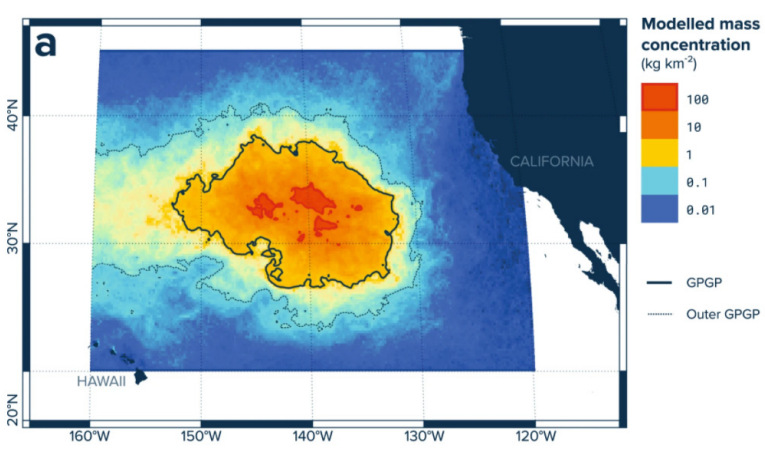

Fig 1. Estimated Area and Mass Concentration of GPGP by Lebreton, et al. [6].

*Corresponding author: wangwm17@mails.jlu.edu.cn (Wang Wenmin) 
Currently, microplastics, defined as plastics with diameter less than $5 \mathrm{~mm}$, have been paid more attention to, particularly their impact on the marine ecosystem [13]. Due to small sizes and wide presence in oceans, lower trophic organisms as a vector such as zooplankton may ingest microplastics, and fishes may eat those trophic organisms with plastic particles unconsciously $[14,15]$. Since both microplastics themselves and their leacheate may release some toxic materials such as polypropylene (PP) and UV stabilizers (2-hydroxy-4-alkoxybenzophenone), these harmful materials may thus accumulate along the food chain and cause health issues on marine creatures, which might even affect human health [15-18].

Therefore, based on current contamination condition, our research focused on microplastics in the ocean by reviewing some previous articles especially on microplastic pollution and toxicity, followed by a discussion on the influences of microplastics on marine ecosystems. Also, our study analyzed the government policies and technologies, and summarized major technologies on tackling marine microplastic problems, providing reference for more efficient waste management on microplastics and better restraint on their negative impacts.

\section{Hazards of microplastics}

In recent years, many studies have been done on the hazards of microplastics to marine organisms, and these studies mainly focus on two aspects: the toxicity of microplastics themselves, and the leaching substances of aging plastics (e.g. additives, residual catalysts, adsorbed toxic chemicals, etc.)

\subsection{The hazards of microplastics themselves}

Plastics have wide application in our life (Table 1). Polypropylene (PP), high-density polyethylene (HDPE), low-density polyethylene (LDPE), polyvinyl chloride (PVC), acrylonitrile butadiene styrene (ABS), polyethylene terephthalate (PET), etc. constitute a significant part of daily necessities. Common plastics are not directly toxic to organisms due to their high degree of polymerization and large molecular weight [19]. However, they are prone to swell and age in the condition of hydrolysis, thermal variation, UV light [10] , and other biological factors [20] in the ocean (Fig.2), separating into lighter fragments [13]. Those with high density will sedimentate to the ocean floor [21], where there is almost no ultraviolet solar radiation, meaning the degradation is hard to proceed and they will stay for long periods. While these relatively smaller ones can be consumed by low-level creatures like plankton, entering the food chains, and

Table 1. Composition of Daily Plastic Products

\begin{tabular}{|c|c|c|c|c|c|}
\hline No. & $\begin{array}{l}\text { Plastic } \\
\text { product }\end{array}$ & Plastic type & No. & Plastic product & Plastic type \\
\hline 1 & Bucket & Polypropylene (PP) & 8 & Liquid soap bottle & $\begin{array}{l}\text { Polyethylene Terephthalate } \\
\text { (PET) }\end{array}$ \\
\hline 2 & DVD case & Polypropylene (PP) & 9 & Soda bottle & $\begin{array}{c}\text { Bio-PET } \\
\text { (up to } 22.5 \% \text { plant } \\
\text { based material) }\end{array}$ \\
\hline 3 & Sports bottle & $\begin{array}{l}\text { High Density } \\
\text { Polyethylene } \\
\text { (HDPE) }\end{array}$ & 10 & Car tire & Polyisoprene Rubber \\
\hline 4 & Q-tips box & $\begin{array}{l}\text { Low Density } \\
\text { Polyethylene } \\
\text { (LDPE) }\end{array}$ & 11 & $\begin{array}{l}\text { Marine epoxy } \\
\quad(\text { filler })\end{array}$ & Epoxy \\
\hline 5 & $\begin{array}{l}\text { Laboratory } \\
\text { gloves }\end{array}$ & Plasticized PVC & 12 & Window frame & Rigid PVC \\
\hline 6 & $\begin{array}{l}\text { Costume } \\
\text { packaging }\end{array}$ & $\begin{array}{l}\text { Polyvinyl Chloride } \\
\text { (PVC) }\end{array}$ & 13 & Phone cover & $\begin{array}{l}\text { Polyurethane } \\
\text { (PUR) }\end{array}$ \\
\hline 7 & $\begin{array}{l}\text { Camping } \\
\text { light casing }\end{array}$ & $\begin{array}{l}\text { Acrylonitrile-butadiene- } \\
\text { styrene (ABS) }\end{array}$ & 14 & $\begin{array}{l}\text { 3D printer } \\
\text { plastic }\end{array}$ & Polylactic Acid (PLA) \\
\hline
\end{tabular}




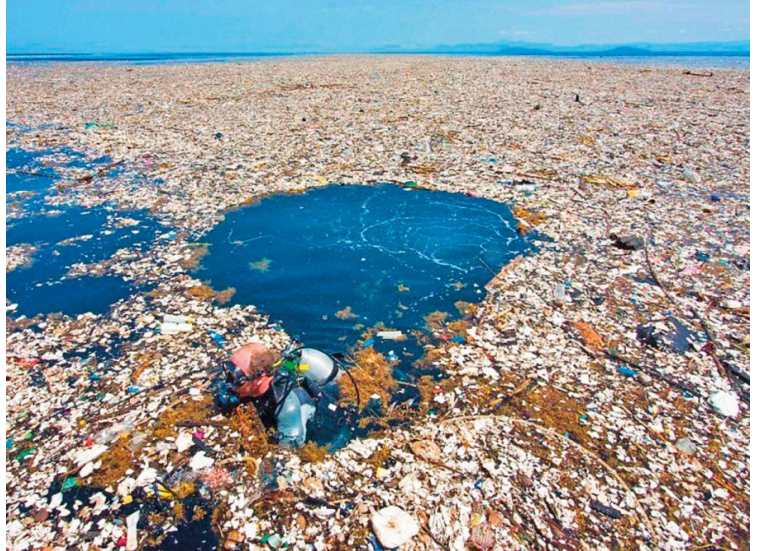

Fig 2. Garbage Floating on the Ocean Surface [56].

will be accumulated in higher-level organisms along the food chain. (Fig.3) The high concentrations of plastics detected in marine fishes [22] have already proven this. Besides, Laurent Seuront's research [23] indicates that microplastics can also affect the transmission of the food chain. This is because some food chains require chemicals to mediate, and microplastics can affect this process. In his research, microplastics caused a direct biological interference effect, inhibiting the behavioral response of intertidal gastropods, making their predation vulnerable.

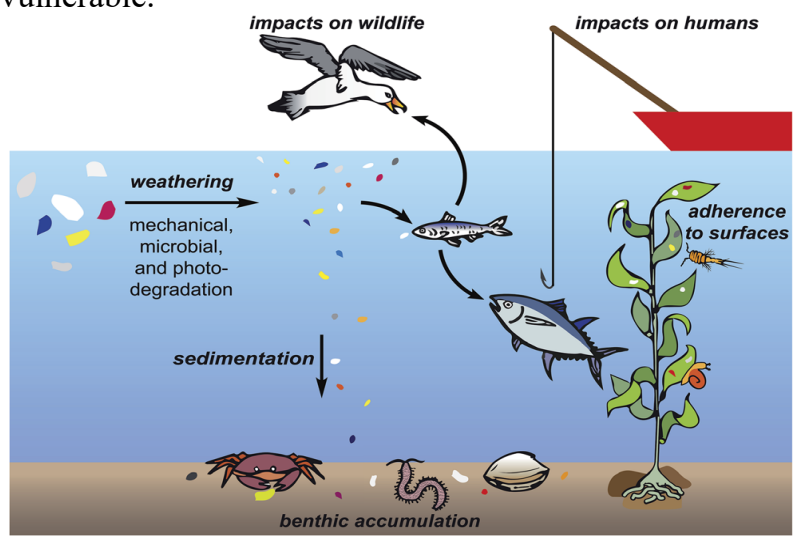

Fig 3. Fate of Plastics in Ocean [57].

\subsection{The hazards of leaching substance}

During the soaking process of the plastic, various kinds of toxic substances will diffuse into the surrounding environment, that is, the leachate. These substances are mainly divided into two categories: chemicals from the plastic production process (e.g., additives) and the release from microplastics after adsorption (e.g., heavy metal ions).

The additives make up the major part of residues.

For instance, UV stabilizers (2-hydroxy-4-alkoxybenzophenone), antibacterial agents (10,10-oxydiphenoxypyrimidine, isothiazole), antioxidants (alkyl phenol, Bisphenol A, Bisphenol A), plasticizers (Phthalates), and brominated flame retardants (BFRs) [Polybromodiphenyl ether (PBDE), hexabromocyclodododecane (HBCD), tetrabromobisphenol A (TBBP). Studies have shown that these additives can bring negative impact on organisms. For example, Jang et al. reported that hexabromocyclododecane (HBDCs) can reduce the survival rate of mussels [24]. And some phthalates are capable of interfering human endocrine even in low concentration [25]. As for the release, the small particle size of the microplastics allows it to have a large specific surface area and thus has strong adsorption capacity to adsorb substances in the ocean, including persistent organic pollutants (POPs) such as Polychlorinated biphenyls (PCBs), Dichloro diphenyltrichloroe thane (DDT), polycyclic aromatic hydrocarbons, and heavy metal ions (e.g. $\left.\mathrm{Zn}^{2+}, \mathrm{Cu}^{2+}\right)[26,27]$. All of these have been detected on beaches around the world. These substances were hard to spread over long distances, but the stable medium of microplastics breaks this restriction. For example, aromatic organic substances such as PCBs have poor water solubility and are difficult to transport by ocean currents. But after being adsorbed on the microplastics, it can spread around the world with the ocean currents with the microplastics as a carrier [28], and can also be ingested into organisms up the food chain, causing further influence to creatures in higher trophic levels. If humans eat seafood with PCBs, their endocrine system will be negatively affected [29]. Heavy metal ions can also harm lives. Taking $\mathrm{Zn}^{2+}$ as an example, it is known to be particularly toxic to aquatic organisms [30].

\section{Improvement measures}

\subsection{Policies}

\subsubsection{Levies}

Recently, levies (a fee for using or dispensing) are a crucial strategy to control MPS pollution at regional levels around the globe [31] which have an influence on consuming behaviors and succeed in Switzerland, Germany, Spain, and other countries [32]. Take Portugal as an example. Since the introduction of the plastic bag tax in 2015, the country's plastic bag consumption has dropped by $74 \%$ [33]. However, the situation in South Africa was on the contrary [34]. Hence, it is explicitly observed that levies have a positive impact (consuming behavior), uncertainty in benefits, and limitations of intervention measures.

Traditional taxation often only targets one type of plastic product, but does not follow the plastic footprint, which has resulted in a large difference between the measured quality of marine plastic waste and the model the actual value is only $1 \%$ of the estimated one [12]. Daoji Li believes that the actual flux of plastics and microplastics into the sea is still unclear [35]. We think that it is resulted from the fewer microplastics footprint researches (sources, transportation) before legislation, thus introduced policies cannot deal with the microplastics pollution at the root.

\subsubsection{Bans}

Since 2009, many countries have issued bans successively prohibiting microbeads (primary plastics) in 
daily necessities which are unanimously regarded by the public as the most effective solution [36]. However, in 2020, some scholars believe that prohibitions are the least popular among consumers because they restrict the freedom of consumption [37]. It is clear that a narrow ban is unreasonable, while a restrictive ban emphasizes circular economy to significantly reduce marine microplastics [38]. However, today's plastic management laws are so independent that there is no connection between the system and one another, and no contact mechanism involved. Hence, the governance of microplastics requires the joint efforts and cooperation of stakeholders and consumers [39]. In the 1990s, Japan followed the rule of "3Rs" (reduce, recycle, reuse) on garbage [40, 41]. In 2018, the European Union(EU) launched European Strategy for Plastics in a Circular Economy [42], which verified the views that guiding opinions, legal support, and guarantees of execution are required. Chung-Sum Lam et al. proposed a conventional plastic legislation strategy to analyze the laws and regulations in the production and transportation of microplastics (Fig.4), and evaluate when and where it is most necessary to implement plastic restrictions, instead of issuing an injunction simply [31]. This is regarded as the beginning of improving the existing ban.

\subsubsection{Voluntary efforts}

Voluntary campaigns have immeasurable development potential. In Portugal, $37 \%$ of supermarkets took the initiative to cancel the distribution of free plastic bags, which resulted in a $64 \%$ collapse [32]. Besides, Australian retailers agreed on the management of plastic bags and reduced the use of plastic bags by $26.9 \%$ [31]. The town of Modbury in the United Kingdom voluntarily implemented the ban on plastic bags, leading to a $48 \%$ decline in plastic consumption in 2009 [43]. However, these regulations are over-dependent on the public, and bring about the following problems:

(1)No clear legal support;

(2)Unclear responsibilities in government departments;

(3)Inadequate participation of social organizations;

(4)The public's unclear understanding of microplastics.

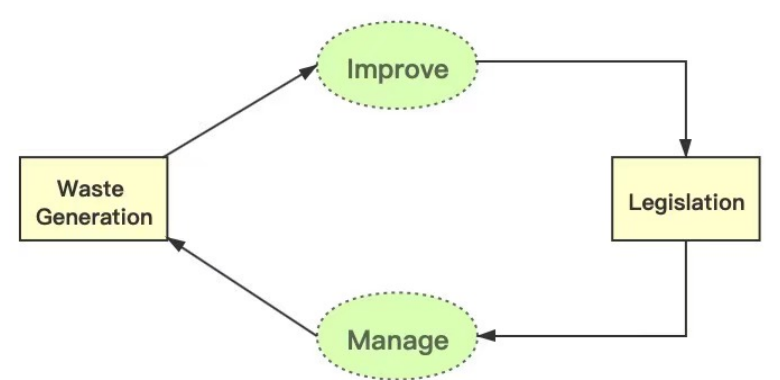

Fig 4. Plastic Legislation Strategy Summarized by Chung-Sum Lam et al. [31].

Lingzhi Deng et al. conducted a public survey in Shanghai, China, and concluded that the public lacked a correct understanding of microplastics and the related laws [44]. Denise M. Mitrano et al. believe that citizen participation in reducing plastic pollution is an extension of the response to deal with the global environmental problems in the last century [38]. Hence, it is a must for the control of microplastics to strengthen the popularization of the masses, so that people will not panic but realize the urgency of governance, and media may be an important medium for disseminating knowledge $[45,46]$.

\subsection{Techniques}

\subsubsection{Physical treatment technology}

Physical treatment technology refers to the use of physical or mechanical separation of sewage treatment, so as to achieve the purpose of removing microplastics in it. Commonly used methods are coagulation, sedimentation, filtration, etc. Coagulation is very effective in removing microplastics. The commonly used chemical coagulants are $\mathrm{Al}_{2}\left(\mathrm{SO}_{4}\right)^{3-\cdot} \cdot 18 \mathrm{H}_{2} \mathrm{O}$ and $\mathrm{Fe}_{2}\left(\mathrm{SO}_{4}\right)_{3}$, both of which are highly efficient and low-cost. Wang et al. (2020) found that the coagulation unit had a removal rate of about $40.5 \%$ to $54.5 \%$ for microplastics [47]. Sedimentation is a process that uses gravity to remove suspended solid particles from liquids and has a high removal rate for suspended particles. Yang et al. (2019) found that the highest removal rate of $91.7 \%$ by the sedimentation unit was achieved in a wastewater treatment plant in Beijing [48]. Filtration specifically includes ultrafiltration, nanofiltration, rapid sand filtration, and hyperfiltration, which have different efficiencies for microplastic removal due to different membrane pore sizes. A study by Magni et al. of an Italian municipal wastewater treatment system found that about $56 \%$ of microplastics could be removed by sand filtration and disinfection [49]. In the study by Wang et al., it was found that granular activated carbon filtration could reduce the abundance of small microplastics from 1 to $5 \mu \mathrm{m}$ by $56.8 \%$ to $60.9 \%$, and for the ultrafiltration process, polyethylene (PE) particles were completely removed due to the small pore size of ultrafiltration membrane with a removal rate of up to $100 \%$ [47].

\subsubsection{Chemical treatment technology}

Chemical treatment technology is the method to remove microplastics by chemical reaction, mainly including chemical precipitation method, redox method, electrolytic method, gas floatation, etc. Removal of microplastics usually uses redox methods such as ozone oxidation, photocatalytic oxidation, and catalytic oxidation with other catalysts. Hidayaturrahman et al. showed that after 30 minutes of ozone treatment, more than $90 \%$ of microplastics were removed [50]. Uheida et al. tested the degradation of low-density polyethylene (LDPE) microplastic residues by irradiating zinc oxide nanorods (ZnO NRs) with visible light. The results of the study showed that the degradation rate of polymer residues was $30 \%$ [51]. Kang et al. found that the degradation of $50 \%$ of microplastics in water bodies within 8 hours was achieved by the action of sulfate 
radicals and hydroxyl radicals [52]. Electrolytic methods and chemical precipitation methods, etc. can also be used to remove plastic leachate to avoid environmental and human health hazards. Zhan et al. used alkaline sulfide to effectively remove $80.60 \% \mathrm{Sb}$ and $90.13 \% \mathrm{Br}$ from flame-retardant plastics from electronic waste [53].

\subsubsection{Biological treatment technology}

Biological treatment technology is a technology that uses the metabolism of microorganisms to achieve the purpose of removing microplastics, mainly including biodegradation, activated sludge method, membrane bioreactor, etc. Yoshida et al. isolated a new type of bacteria with PET as the main carbon source. The bacteria could hydrolyze the surface of PET film at 0.13 $\mathrm{mg} /\left(\mathrm{cm}^{2} \cdot \mathrm{d}\right)$ at $30^{\circ} \mathrm{C}$ [54]. The study by Magni et al. for the Italian municipal wastewater treatment system found that about $64 \%$ of microplastics were removed after the grid chamber and conventional activated sludge processes [49]. Lares et al. found $99.4 \%$ of microplastic could be removed after using a membrane bioreactor process on wastewater from a municipal wastewater treatment plant near the city center of Mikkeli, Finland [55].

\subsubsection{Comparison of microplastics treatment techniques}

The physical technology is simple to operate, but the removal efficiency is not fixed, and may not really remove microplastics. Ultrafiltration technology has higher removal efficiency in physical technology and can be popularized in the field of microplastic treatment. The removal efficiency of chemical technology is higher than that of physical technology. Due to its high removal rate for microplastics, ozone technology is currently the most widely used technology for treating microplastics in water bodies. Biotechnology is more energy-efficient and less costly. The activated sludge process is still the mainstream process. Although the removal efficiency of membrane bioreactor is the highest, it is not suitable for popularizing in sewage treatment plants. The specific advantages and disadvantages of treatment techniques are compared in Table 2 .

\section{Suggestions}

We recommend that the microplastics treatment plan meets the following four requirements: (1) More marine microplastics research before legislation. Trace the source of microplastics into the sea and clarify the plastic footprint. New virgin polymers can be substituted for recycled plastic polymers to reduce greenhouse gas emissions and fuel consumption. (2) More complete and sound regulations of public participation. Protect citizens' litigation rights and the right to know the status quo of the environment. (3) More inter-organizational cooperation. Reach a consensus on the specific issues of marine plastics and promote multiparty cooperation by establishing a linkage mechanism. (4) More microplastics knowledge popularization. Facilitate the investigation and reporting of plastic issues and arrange courses on microplastics and plastic management law in school.

Moreover, a single technology has a poor impact on the removal of microplastics, thus in the future, different technologies (traditional and advanced treatment) can be combined which can effectively reduce the abundance of microplastics. Besides, we can combine different processes, and it is expected to become the mainstream process in current sewage treatment. We suggest that it can be widely studied in the field of water treatment and it is necessary to promote the application in the removal part.

In addition, solutions based on bioengineering may also be new ways to degrade plastics in the ocean, including wastewater treatment plants (WWTP) and so

Table 2. Comparison of Microplastics Treatment Techniques

\begin{tabular}{|c|c|c|c|c|}
\hline \multicolumn{2}{|c|}{ Treatment technology } & Advantages & Disadvantages & References \\
\hline \multirow{6}{*}{$\begin{array}{l}\text { Physical treatment } \\
\text { technology }\end{array}$} & Coagulation & $\begin{array}{c}\text { Removal rate of } \\
\text { about } 40.5 \% \\
\text { to } 54.5 \%\end{array}$ & $\begin{array}{l}\text { Smaller microplastics } \\
\text { have low removal rate }\end{array}$ & [47] \\
\hline & Sedimentation & $\begin{array}{l}\text { Removal rate } \\
\text { can reach } 90 \%\end{array}$ & $\begin{array}{l}\text { Sedimentation can only } \\
\text { be removed with the } \\
\text { sludge }\end{array}$ & {$[48,58]$} \\
\hline & Sand filtration & $\begin{array}{c}\text { Removal rate of } \\
56 \%\end{array}$ & $\begin{array}{c}\text { Different water plants } \\
\text { have different removal } \\
\text { rates }\end{array}$ & {$[49]$} \\
\hline & Ultrafiltration & $\begin{array}{c}\text { PE particles are } \\
\text { completely removed }\end{array}$ & $\begin{array}{c}\text { Ultrafiltration } \\
\text { membrane scaling }\end{array}$ & {$[47]$} \\
\hline & Reverse osmosis & $\begin{array}{l}90.45 \% \text { of plastic } \\
\text { fragments }(>25 \mu \\
\text { m)can be captured }\end{array}$ & Membrane fouling & [59] \\
\hline & $\begin{array}{l}\text { Granular activated } \\
\text { carbon filtration }\end{array}$ & $\begin{array}{c}\text { Reduce the } \\
\text { abundance of small } \\
\text { microplastics from } 1\end{array}$ & $\begin{array}{c}\text { Large losses } \\
\text { in the process of use } \\
\text { cause high costs. }\end{array}$ & {$[47]$} \\
\hline
\end{tabular}




\begin{tabular}{|c|c|c|c|c|}
\hline & & $\begin{array}{c}\text { to } 5 \mu \mathrm{m} \text { by } 56.8 \% \text { to } \\
60.9 \%\end{array}$ & & \\
\hline \multirow{2}{*}{$\begin{array}{c}\text { Chemical treatment } \\
\text { technology }\end{array}$} & Ozone oxidation & $\begin{array}{c}\text { Removal rate can } \\
\text { reach } 90 \%\end{array}$ & $\begin{array}{l}\text { High energy } \\
\text { consumption }\end{array}$ & {$[51]$} \\
\hline & $\begin{array}{c}\text { Photocatalytic } \\
\text { oxidation }\end{array}$ & Non-toxic & $\begin{array}{c}\text { Technology is not } \\
\text { mature yet }\end{array}$ & {$[52]$} \\
\hline \multirow{3}{*}{$\begin{array}{c}\text { Biological treatmen } \\
\text { t technology }\end{array}$} & Biodegradation & $\begin{array}{c}\text { Efficient } \\
\text { degradation, low } \\
\text { cost }\end{array}$ & $\begin{array}{c}\text { Environmental } \\
\text { parameters limit the } \\
\text { process of } \\
\text { biodegradation }\end{array}$ & {$[54]$} \\
\hline & Activated sludge & $\begin{array}{c}\text { Removal rate can } \\
\text { reach } 66.7 \%\end{array}$ & $\begin{array}{c}\text { Removal rate is not } \\
\text { stable }\end{array}$ & {$[49,59]$} \\
\hline & $\begin{array}{l}\text { Membrane } \\
\text { bioreactor }\end{array}$ & $\begin{array}{l}\text { Removal rate can } \\
\text { reach } 99.9 \%\end{array}$ & $\begin{array}{l}\text { Removal efficiency of } \\
\text { microplastics is } \\
\text { affected by the } \\
\text { thickness of biofilm, } \\
\text { membrane blockage } \\
\text { and liquid distribution }\end{array}$ & {$[55,60]$} \\
\hline
\end{tabular}

forth. Since the removal rate of MPs depends on WWTP, we need to test the best environmental conditions for the MPs removal, find out the key factors, and simulate the best environment in common marine waters. Eco-friendly schemes have a wide range, but there are few studies. We suggest strengthening this part of the research.

\section{Conclusion}

Microplastics pollution has been highly concerned nowadays since it has brought some negative effects on the marine ecosystem. The toxicity of microplastics is reflected in different aspects, including accumulation in organisms, interference to some food chain, and sedimentation on the seabed, etc. In addition, it is harmful to aquatic organism and, also, human health is affected through intaking polluted seafood. Current policies have effects on tackling marine microplastics problems in the aspects of Levies, Bans and Voluntary efforts, while some issues including lack of "plastic footprint", isolated management methods, and poor popularizing rate are still urgently to be solved. Furthermore, through the analysis of the currently widely-used microplastics treatment technology on physical, chemical and biological aspects respectively, our work provides reference for the actual treatment process according to different factors such as treatment efficiency, cost, effect and so on. And we advised on more research on marine microplastics as well as inter-organizational cooperation in marine protection. Campaigns on popularization of microplastics-related knowledge should also be launched for better public participation afterward. In the future, more attempt on combining different methods and solutions based on bioengineering is important on creating a cleaner marine environment. And there are still more to be done to better solve this long-lasting microplastics problems in oceans unitedly.

\section{Reference}

1. PlasticsEurope, PlasticsEurope (2020) Plastics - the Facts 2020. An analysis of European plastics production, demand and waste data. , (22 January 2021).

2. W.H. Organization, Water, sanitation, hygiene, and waste management for the COVID-19 virus: interim guidance, 23 April 2020, World Health Organization, 2020.

3. M.T. Mehran, S. Raza Naqvi, M. Ali Haider, M. Saeed, M. Shahbaz, T. Al-Ansari, Global plastic waste management strategies (Technical and behavioral) during and after COVID-19 pandemic for cleaner global urban life, Energy Sources, Part A: Recovery, Utilization, and Environmental Effects (2021) 1-10.

4. Y. Tokiwa, B.P. Calabia, C.U. Ugwu, S. Aiba, Biodegradability of plastics, International journal of molecular sciences 10(9) (2009) 3722-3742.

5. J.R. Jambeck, R. Geyer, C. Wilcox, T.R. Siegler, M. Perryman, A. Andrady, R. Narayan, K.L. Law, Plastic waste inputs from land into the ocean, Science 347(6223) (2015) 768-771.

6. L. Lebreton, B. Slat, F. Ferrari, B. Sainte-Rose, J. Aitken, R. Marthouse, S. Hajbane, S. Cunsolo, A. Schwarz, A. Levivier, Evidence that the Great Pacific Garbage Patch is rapidly accumulating plastic, Scientific reports 8(1) (2018) 1-15.

7. J.L. Lavers, A.L. Bond, Exceptional and rapid accumulation of anthropogenic debris on one of the world's most remote and pristine islands, Proceedings of the National Academy of Sciences 114(23) (2017) 6052-6055.

8. S.i. Kako, A. Isobe, S. Seino, A. Kojima, Inverse estimation of drifting-object outflows using actual 
observation data, Journal of oceanography 66(2) (2010) 291-297.

9. D.K. Barnes, F. Galgani, R.C. Thompson, M. Barlaz, Accumulation and fragmentation of plastic debris in global environments, Philosophical transactions of the royal society B: biological sciences 364(1526) (2009) 1985-1998.

10. A.L. Andrady, Microplastics in the marine environment, Marine pollution bulletin 62(8) (2011) 1596-1605.

11. J. Kaiser, The dirt on ocean garbage patches, American Association for the Advancement of Science, 2010.

12. A. Cózar, F. Echevarría, J.I. González-Gordillo, X. Irigoien, B. Úbeda, S. Hernández-León, Á.T. Palma, S. Navarro, J. García-de-Lomas, A. Ruiz, Plastic debris in the open ocean, Proceedings of the National Academy of Sciences 111(28) (2014) 10239-10244.

13. R.C. Thompson, Y. Olsen, R.P. Mitchell, A. Davis, S.J. Rowland, A.W. John, D. McGonigle, A.E. Russell, Lost at sea: where is all the plastic?, Science(Washington) 304(5672) (2004) 838.

14. S.L. Wright, R.C. Thompson, T.S. Galloway, The physical impacts of microplastics on marine organisms: a review, Environmental pollution 178 (2013) 483-492.

15. Y. Li, Y. Sun, J. Li, R. Tang, Y. Miu, X. Ma, Research on the Influence of Microplastics on Marine Life, IOP Conference Series: Earth and Environmental Science, IOP Publishing, 2021, p. 012006.

16. S. Sharma, S. Chatterjee, Microplastic pollution, a threat to marine ecosystem and human health: a short review, Environmental Science and Pollution Research 24(27) (2017) 21530-21547.

17. D. Lithner, I. Nordensvan, G. Dave, Comparative acute toxicity of leachates from plastic products made of polypropylene, polyethylene, PVC, acrylonitrile-butadiene-styrene, and epoxy to Daphnia magna, Environmental Science and Pollution Research 19(5) (2012) 1763-1772.

18. J.-P.W. Desforges, M. Galbraith, P.S. Ross, Ingestion of microplastics by zooplankton in the Northeast Pacific Ocean, Archives of environmental contamination and toxicology 69(3) (2015) 320-330.

19. R.D. Deanin, Additives in plastics, Environmental Health Perspectives 11 (1975) 35-39.

20. B. Gewert, M.M. Plassmann, M. MacLeod, Pathways for degradation of plastic polymers floating in the marine environment, Environmental Science: Processes \& Impacts 17(9) (2015) 1513-1521.
21. L.C. Woodall, A. Sanchez-Vidal, M. Canals, G.L. Paterson, R. Coppock, V. Sleight, A. Calafat, A.D. Rogers, B.E. Narayanaswamy, R.C. Thompson, The deep sea is a major sink for microplastic debris, Royal Society open science 1(4) (2014) 140317.

22. F. Ferrara, N. Ademollo, M. Delise, F. Fabietti, E. Funari, Alkylphenols and their ethoxylates in seafood from the Tyrrhenian Sea, Chemosphere 72(9) (2008) 1279-1285.

23. L. Seuront, Microplastic leachates impair behavioural vigilance and predator avoidance in a temperate intertidal gastropod, Biology letters 14(11) (2018) 20180453.

24. M. Jang, W.J. Shim, G.M. Han, M. Rani, Y.K. Song, S.H. Hong, Styrofoam debris as a source of hazardous additives for marine organisms, Environmental science \& technology 50(10) (2016) 4951-4960.

25. J. Oehlmann, U. Schulte-Oehlmann, W. Kloas, O. Jagnytsch, I. Lutz, K.O. Kusk, L. Wollenberger, E.M. Santos, G.C. Paull, K.J. Van Look, A critical analysis of the biological impacts of plasticizers on wildlife, Philosophical Transactions of the Royal Society B: Biological Sciences 364(1526) (2009) 2047-2062.

26. K. Ashton, L. Holmes, A. Turner, Association of metals with plastic production pellets in the marine environment, Marine pollution bulletin 60(11) (2010) 2050-2055.

27. L.A. Holmes, A. Turner, R.C. Thompson, Interactions between trace metals and plastic production pellets under estuarine conditions, Marine Chemistry 167 (2014) 25-32.

28. I. Velzeboer, C. Kwadijk, A. Koelmans, Strong sorption of PCBs to nanoplastics, microplastics, carbon nanotubes, and fullerenes, Environmental science \& technology 48(9) (2014) 4869-4876.

29. B. Ulbrich, R. Stahlmann, Developmental toxicity of polychlorinated biphenyls (PCBs): a systematic review of experimental data, Archives of toxicology 78(5) (2004) 252-268.

30. W. Sunda, P. Tester, S. Huntsman, Effects of cupric and zinc ion activities on the survival and reproduction of marine copepods, Marine Biology 94(2) (1987) 203-210.

31. C.-S. Lam, S. Ramanathan, M. Carbery, K. Gray, K.S. Vanka, C. Maurin, R. Bush, T. Palanisami, A Comprehensive Analysis of Plastics and Microplastic Legislation Worldwide, Water, Air, \& Soil Pollution 229(11) (2018) 345.

32. I.P. Luís, H. Spínola, The influence of a voluntary fee in the consumption of plastic bags on supermarkets from Madeira Island (Portugal), Journal of Environmental Planning and 
Management 53(7) (2010) 883-889.

33. G. Martinho, N. Balaia, A. Pires, The Portuguese plastic carrier bag tax: The effects on consumers' behavior, Waste management 61 (2017) 3-12.

34. J. Dikgang, A. Leiman, M. Visser, Analysis of the plastic-bag levy in South Africa, Resources, Conservation and Recycling 66 (2012) 59-65.

35. D. Li, Research advance and countermeasures on marine microplastic pollution, Research in Environmental Science 32 (2019) 21-26.

36. K. Lei, F. Qiao, Q. Liu, Z. Wei, H. Qi, S. Cui, X. Yue, Y. Deng, L. An, Microplastics releasing from personal care and cosmetic products in China, Marine pollution bulletin 123(1-2) (2017) 122-126.

37. M. Carrigan, C. Moraes, S. Leek, Fostering Responsible Communities: A Community Social Marketing Approach to Sustainable Living, Journal of Business Ethics 100(3) (2011) 515-534.

38. D.M. Mitrano, W. Wohlleben, Microplastic regulation should be more precise to incentivize both innovation and environmental safety, Nature Communications 11(1) (2020) 5324.

39. F. Convery, S. McDonnell, S. Ferreira, The most popular tax in Europe? Lessons from the Irish plastic bags levy, Environmental and Resource Economics 38(1) (2007) 1-11.

40. P. Kershaw, Sources, fate and effects of microplastics in the marine environment: a global assessment, International Maritime Organization, 2015.

41. B. Worm, H.K. Lotze, I. Jubinville, C. Wilcox, J. Jambeck, Plastic as a Persistent Marine Pollutant, Annual Review of Environment and Resources 42(1) (2017) 1-26.

42. E. Foschi, A. Bonoli, The commitment of packaging industry in the framework of the European strategy for plastics in a circular economy, Administrative Sciences 9(1) (2019) 18.

43. O. Ayalon, T. Goldrath, G. Rosenthal, M. Grossman, Reduction of plastic carrier bag use: An analysis of alternatives in Israel, Waste Management 29(7) (2009) 2025-2032.

44. A. Lusher, P. Hollman, J. Mendoza-Hill, Microplastics in fisheries and aquaculture: status of knowledge on their occurrence and implications for aquatic organisms and food safety, FAO2017.

45. S.M. Friedman, S. Dunwoody, C.L. Rogers, Communicating uncertainty: Media coverage of new and controversial science, Routledge1999.

46. C. Völker, J. Kramm, M. Wagner, On the creation of risk: framing of microplastics risks in science and media, Global Challenges 4(6) (2020) 1900010.

47. Z. Wang, T. Lin, W. Chen, Occurrence and removal of microplastics in an advanced drinking water treatment plant (ADWTP), Science of The Total Environment 700 (2020) 134520.

48. L. Yang, K. Li, S. Cui, Y. Kang, L. An, K. Lei, Removal of microplastics in municipal sewage from China's largest water reclamation plant, Water Research 155 (2019) 175-181.

49. S. Magni, A. Binelli, L. Pittura, C.G. Avio, C. Della Torre, C.C. Parenti, S. Gorbi, F. Regoli, The fate of microplastics in an Italian Wastewater Treatment Plant, Science of The Total Environment 652 (2019) 602-610.

50. H. Hidayaturrahman, T.-G. Lee, A study on characteristics of microplastic in wastewater of South Korea: Identification, quantification, and fate of microplastics during treatment process, Marine Pollution Bulletin 146 (2019) 696-702.

51. A. Uheida, H.G. Mejía, M. Abdel-Rehim, W. Hamd, J. Dutta, Visible light photocatalytic degradation of polypropylene microplastics in a continuous water flow system, Journal of Hazardous Materials (2020) 124299.

52. J. Kang, L. Zhou, X. Duan, H. Sun, Z. Ao, S. Wang, Degradation of Cosmetic Microplastics via Functionalized Carbon Nanosprings, Matter 1(3) (2019) 745-758.

53. L. Zhan, X. Zhao, Z. Ahmad, Z. Xu, Leaching behavior of $\mathrm{Sb}$ and $\mathrm{Br}$ from E-waste flame retardant plastics, Chemosphere 245 (2020) 125684.

54. S. Yoshida, K. Hiraga, T. Takehana, I. Taniguchi, H. Yamaji, Y. Maeda, K. Toyohara, K. Miyamoto, Y. Kimura, K. Oda, A bacterium that degrades and assimilates poly (ethylene terephthalate), Science 351(6278) (2016) 1196-1199.

55. M. Lares, M.C. Ncibi, M. Sillanpää, M. Sillanpää, Occurrence, identification and removal of microplastic particles and fibers in conventional activated sludge process and advanced MBR technology, Water Research 133 (2018) 236-246.

56. Pictures of Garbage floating on the ocean surface, [Online],viewed on February 25th,available at https://images.app.goo.gl/UmFG3b1grQmRGetw6.

57. V.S. Lin, Research highlights: impacts of microplastics on plankton, Environmental Science: Processes \& Impacts 18(2) (2016) 160-163.

58. X.L. Q, L. S, L. Y, L.Y. D, X. Q, Removal of microplastics in different wastewater treatment process in Harbin municipal wastewater treatment plants \%J Acta Scientiae Circumstantiae, 40(11) (2020) 3964-3970.

59. S. Ziajahromi, P.A. Neale, L. Rintoul, F.D.L. Leusch, Wastewater treatment plants as a pathway for microplastics: Development of a new approach to sample wastewater-based microplastics, Water Research 112 (2017) 93-99. 
60. J. Talvitie, A. Mikola, A. Koistinen, O. Setälä, Solutions to microplastic pollution - Removal of microplastics from wastewater effluent with advanced wastewater treatment technologies, WaterResearch 123 (2017) 401-407. 